\title{
Development of personnel safety awareness scale (PSAS) for 3th. and 4 th. grade primary school students ${ }^{1}$
}

\author{
Sedef Ünsal Seydooğulları, Ministry of Education, Cahit Elginkan Anatolian High School, Turkey, \\ sedefunsal@gmail.com, ORCID: 0000-0001-9067-1999 \\ Emine Gül Kapçı, Ankara University (Retired Faculty Member), Turkey, eminegulkapci@gmail.com, ORCID: \\ 0000-0002-5094-9244
}

\begin{abstract}
The aim of present study is to develop a measurement tool to assess the knowledge and awareness of 3rd and 4th grade students about prevention of sexual abuse. Participants were 718 students (girl $n=381$; boy $n=337$ ) attending 3rd and 4th grades of primary schools in Kocaeli. Tetracoric factor analysis revealed that the scale consisted of 20 items. Item loads ranged .38 and .79, explaining $41 \%$ of total variance. Concurrent validity was assessed with the "Good Touch Bad Touch Scale" and was found to be .66. The internal consistency coefficient was assessed with KR-20 $\mathrm{r}=.85$. Test-retest correlation was .79. Findings showed that PSAS could be used to assess the knowledge and awareness of 3rd and 4th grade primary school students about sexual abuse.
\end{abstract}

Keywords: Students, personnel safety, personnel safety awareness, sexual abuse

Received: 28.06 .2019

Accepted:19.07.2020

Published: 15.01 .2021

\section{INTRODUCTION}

Child sexual abuse, which affects children and communities and whose short and long-term devastating consequences continue in adulthood, is considered as a universal problem. For this reason, the interest of many institutions, organizations and non-governmental organizations has focused on this issue. First, in the 1970s, two feminist writers Florence Rush (1980) and Judith Herman (1984) expressed their views on the subject. Then, the prevalence study that Russell (1983) revealed that $38 \%$ of women were exposed to sexual abuse in their childhood, increased the attention to the subject. According to researches, the rate of sexual abuse of 17-year-old girls in the USA was $26.6 \%$, and boys were reported as 5.1\% (Finkelhor, 2014). In America, 13\% of adult men and $30 \%$ of adult women reported that they were sexually abused in their childhood (Finkelhor, 2009). According to the report of the Council of Europe Convention on the Protection of Children Against Sexual Abuse (2007), it is reported that one in every five children in Europe is exposed to sexual abuse. Meta-analysis research results also showed that the prevalence of child and adolescent sexual abuse worldwide is 11.8\% (Stoltenborgh et al., 2011).

In addition to the prevalence studies, short and long term effects of sexual abuse are among the topics that researchers focus on. Children who are sexually abused can experience posttraumatic stress disorder (Putnam, 2003) and anxiety and depression disorder (Nickel et al., 2004). In addition to social problems such as run away from home and adolescent pregnancy (Roberts, O'Connor, Dunn, Golding \& ALSPAC, 2004), it is stated that the life satisfaction (Nickel et al, 2004; Fergusson, Geraldine, Mcleod \& Horwood, 2013) and academic success of these children have decreased (Boden, Horwood \& Fergusson, 2007; Currie \& Spatz Widom, 2010). In addition, they experience various problems in interpersonal relationships (Csorba, Tsikouras, Lampe \& Poka, 2012; Tailor, Piotrowski, Woodgate \& Letourneau, 2014). Sexual abuse, which results in a serious physical, psychological and social injury, causes a wide range of mental problems such as anxiety, depression, self-harm, suicide attempt (Paolucci, Genuis \& Violato, 2001, Fergussonet al., 2013; Maniglio, 2014), eating disorders, risky sexual behavior, substance abuse (Nickel et al., 2004; Dube et al., 2005; Fergusson et al., 2013) in adult life.

\footnotetext{
1 This research was produced from a part of the doctoral dissertation conducted by the first author under the supervision of the second author. In addition, a poster notice was presented at the 1st Cognitive Therapies Congress held in Ankara between 18-21 October 2018.
} 
All these results made it necessary to plan preventive studies on sexual abuse. At the beginning of the measures taken are to punish the abuser with heavy crimes to deter potential abusers, to raise public awareness and to invite the public to sensitivity through media campaigns. In addition, awareness raising activities for families are some of the measures taken (Mendelson \& Letourneau, 2015). In recent years, psycho-education programs have been started to be developed in order to ensure that children have the necessary knowledge and skills for the possibility of encountering risky situations and thus empower children (Wurtele, 2009). Schoolbased education programs aim to raise awareness of children's right to protect themselves and their bodies, to gain the ability to distinguish abuse potential (good / bad touch) and reject them, and to develop confidence in sharing with an adult they trust when they realize or experience potential abuse (Ziyalar, 1998; Wurtele \& Kenny, 2010). It is envisaged that students who develop rejection skills through education programs, can realize the risky and dangerous situations, and who can exhibit the safe behavior required in these situations, can protect themselves from sexual abuse. The results of the studies conducted to see the long-term effects of the programs support this prediction (Fryer, Kraizer \& Miyoshi, 1987; Maclntyre \& Carr, 1999; Gibson \& Leitenberg, 2000).

Education programs, which started to be developed in the USA and Canada since the 1980s and which are widely applied in schools in many countries of the world, are considered as one of the most effective measures to prevent child abuse. However, there are limited number of education programs (Ziyalar, 1998; Çeçen-Eroğul ve Kaf-Hasırcı, 2013; Uçar, 2014; Seydooğulları ve Kapçı, 2018) and assesment tools in this issue in Turkey. However, assessments of children's level of knowledge and awareness are of great importance in terms of being a guide for measures to be taken in this regard. The level of knowledge and awareness of children on this issue should be determined in order for children to be able to achieve the purpose of safety training aimed at protecting themselves, distinguishing between safe and unsafe situations, and exhibiting safe behavior. It is important to identify the existing situation in order to the training programs to achieve their goals. Therefore, measurement tools are needed both to determine the level of awareness of children and to evaluate the effectiveness of various measures taken. In addition to the scientific evaluation of the effectiveness of the measures taken, it is seen as an important need to have measurement tools that can be used in the applications to be made in schools.

When reference is made to the relevant literature, it is seen that there are measurement tools related to personal safety information and awareness in abroad. One of these scales belongs to Tutty (1995). Tutty (1995) developed the "Children's Knowledge of Abuse QuestionnaireRevised (CKAQ-R)" for primary school students to test the effectiveness of the child sexual abuse prevention program "Who Do You Tell". The scale consists of 33 items that require marking whether the items given about the abuse are correct and aims to measure the level of knowledge of students about the prevention of sexual abuse. Another measuring tool is "What If Situation Test" developed by Wurtele, Hughes and Owens (1998). In this scale, case studies are given in the form of "What....... if" and the children are asked to indicate what to do or say in the given event by marking one of the options. In addition, the "Personal Safety Scale" (Wurtele, Gillispie, Currier, \& Franklin, 1992), which aims to measure the level of knowledge of children about sexual abuse, consists of 12 questions that measure personal safety knowledge. Similar to other measurement tools, it requires the respondent to provide an opinion about the accuracy or inaccuracy of the statements given.

In Turkey, the only scale that can be achieved is "Good Touch-Bad Touch Scale" developed by Church, Forehand, Brown and Holmes (1988). The adaptation studies of the scale were done by Çeçen-Eroğul and Kaf-Hasırcı (2013). The scale consists of one dimension and 10 items and includes questions aimed at determining whether the child is able to distinguish good / bad touch, whether he/she knows ways to deal with sexual abuse, and whether he/she uses this information in the face of certain events. This scale consists of questions only about touches and ways to be followed in case of sexual abuse and does not include risks in the virtual environment. It has been observed that there is no measurement tool for measuring children's knowledge and awareness of virtual sexual abuse, abuse situation, safe/unsafe events and situations, precautions to be taken 
when a risky event is encountered. Sexual abuse has reached alarming proportions in the world and Turkey (Finkelhor, 2009; Stoltenborgh et al., 2011; Finkelhor, 2014; TÜIIK, 2017).

Therefore, children's awareness of self-protection is very important. Based on this requirement, the main problem of this research is the need for a tool that evaluates children's knowledge and awareness of sexual abuse. The main purpose of the research is to develop a measurement tool for determining the level of knowledge and awareness of 3rd and 4th grade students about sexual abuse.

\section{METHODS}

\section{Working Group}

The working group of the study consists of 718 students attending the 3 rd and 4 th grades of primary schools in Kocaeli province Izmit, Derince, Körfez and Basiskele districts. 381 of the students are girls (53\%) and 337 are boys (47\%). 304 continues to 3rd grade (42\%), 414 continues to 4 th grade (58\%). All schools are public schools. One of the schools belongs to the middle and upper socio-economic level (SED), the others belong to the middle and lower SED.

\section{Instruments}

In this study, the Personal Safety Awareness Scale (PSAS) developed by the researchers and the Good Touch Bad Touch Scale (GTBTS) developed by Church, Forehand, Brown and Holmes (1988) were used.

\section{Personal safety awareness scale (PSAS)}

PSAS was developed by researchers within the scope of this study. To measure the level of knowledge of children about sexual abuse has been reached to developed measurement tools in abroad and Turkey. The scales reached were examined. A pool of 89 items have been created which is thought to measure whether children are aware of their rights, whether they distinguish good/ bad touch, whether they know the safety rules they will use when faced with an abuse situation or whether they discriminate between good/ bad secret.

In order to see the suitability of the determined items for 3rd and 4th grade levels, a preliminary application was made individually with 10 students who went to 3rd and 4th grade. While practicing, some questions were revised as it was seen that some students had difficulties in understanding expressions such as "abuse", "neglect", "physical", "emotional", "right". The corrected items were presented to the class teachers' opinion.

Symptom table and expert opinion forms were prepared and presented to the evaluations of four academicians, two class teachers and two psychological counselors. Experts' opinions are that all items are appropriate. However, some statements had correction suggestions. For example; "Strangers are dangerous" statement corrected as a "Strangers are generally dangerous people." Similarly, "It is normal that adults do not meet the needs of children when they have a lot of work" statement has been changed to "It is normal that parents do not meet the needs of children when they have a lot of work". In addition, changes regarding the use of suffixes in some sentences have been proposed. After the related corrections were made, the 89-item scale was applied to the 3rd and 4th grades of primary schools in Kocaeli in December 2016 to collect data for validity and reliability analyzes.

A sample situation is given in PSAS. In this case, there are 11 items that require marking the closest of the options regarding what to do or what to say. In addition, there are 9 items that require him / her to mark his / her thoughts about the true or false of a sentence about personal safety. Unlike the scales that can be reached, there are also questions in PSAS that measure the safety information of children in the virtual environment.

The items of PSAS are in the form of marking the correct one of the three answer options as given in the example below:

If an adult touches your private area and says "it's a secret between us", what behavior do you do? 
a. I tell my best friend

b. I tell an adult I trust

c. I don't tell anyone because it's a secret.

Children have the right to say "no" to the confusing touches.

a. True

b. False

c. I do not know

The increase in the total score formed by evaluating the answer "1" for each correct answer, "0" for each wrong or I do not know, indicates that the student has more information about personal safety and protection from abuse. In this case, the highest score that can be obtained from the scale is " 20 " and the lowest score is "0".

\section{Good Touch/Bad Touch Scale (GTBTS)}

In this research, "Good Touch Bad Touch Scale", which was developed by Church, Forehand, Brown and Holmes (1988) and adapted to Turkish children by Çeçen-Eroğul and Kaf-Hasırcl (2013), was used to test the similar scale validity of the Personal Safety Awareness Scale. The scale consists of 10 items designed to measure the level of knowledge of primary school students about sexual abuse. There are 3 options for each question. Each correct answer of the student is scored as " 1 ", and every wrong and I don't know answer is scored as " 0 ". The highest score to be taken from the scale is "10" and the lowest score is "0". The high score indicates the high level of knowledge of the student regarding sexual abuse. Confirmatory factor analysis was carried out by Çeçen-Eroğul and Kaf-Hasırcı (2013) to evaluate the factor structure of the scale, which was first translated into Turkish. As a result of the analysis made with the Mplus 5.21 program, the one-dimensional structure of the scale was confirmed. Fit indices are at acceptable levels (chisquare $=30.96, \mathrm{df}=25, \mathrm{p}>.190, \mathrm{CFI}=.90, \mathrm{TLI}=.88, \mathrm{RMSEA}=.028)$. The coefficient calculated with the KR-21 formula for the internal consistency of the scale is .78. Test-retest reliability is .80 .

\section{Procedure}

After presenting the scale items determined based on the literature review to the expert opinions, necessary corrections and improvements were made and necessary permissions were applied for the application of the 89-item measurement tool. The necessary permission was obtained from the Ethics Committee of Ankara University to collect data in order to perform the validity and reliability studies of the scale. Following the permission of the ethics committee, Kocaeli National Education Directorate was applied and a research permit was obtained. Approval was obtained from the families of the students to be applied scale in the determined schools through the "Family Consent Form". Also, the students filled out the "Student Volunteering Form" that they volunteered to participate. Students who do not want to participate are not included in the application.

Applications continued throughout December 2016. The aim of the research was explained to the students before the application, which lasted about 2 hours, and it was stated that the confidentiality of the information would be protected. The 89-item tool was applied to a group of 446 students primarily to perform exploratory factor analysis. The 20 -item scale obtained after exploratory factor analysis was applied to another sample of 272 people to test whether the factor structure was confirmed or not. Confirmatory factor analysis was performed on the obtained data. In test-retest applications, the time between the two applications was determined as four weeks, as indicated in the relevant literature (Büyüköztürk, 2011). Four weeks later, 79 participants were reapplied.

\section{Data Analysis}

Construct validity, $27 \%$ lower-upper group comparison and similar scale validity methods were used for validity studies of PSAS. In addition, item discrimination index and item difficulty index 
were calculated and item analyzes were performed. In order to determine the factor structure of the test, exploratory factor analysis was performed on the tetracoric correlation matrix using the FACTOR 10.0 program. Tetracoric correlation analysis is used to determine the degree of relationship between two variables with two categories artificial discontinuous (Kan, 2011). In this study, the answers given by the students to the items in the test were artificially made into two categories as 1-0. For this reason, tetracoric correlation analysis was used to determine the factor structure. LISREL 8.8 program was used to apply confirmatory factor analysis to the 20item structure obtained by exploratory factor analysis. The reliability of PSAS was determined by calculating the internal consistency coefficient and test-retest correlation. SPSS.22 program was used for reliability calculations.

\section{RESULTS}

In this section, findings related to validity and reliability analysis of PSAS are given.

\section{Findings Regarding Validity Studies of PSAS}

\section{Construct Validity of PSAS}

PSAS, consisting of a total of 89 items, was applied to 3rd and 4th grade students in five different primary schools to conduct validity studies. The distribution of the participants by grade level and gender is given in Table 1.

Table 1. Distribution of PSAS participants exploratory factor analysis according to grade level and gender

\begin{tabular}{lrrr} 
& \multicolumn{2}{c}{ Gender } & \\
& Female & Male & Total \\
\cline { 2 - 4 } & $\mathbf{n}(\%)$ & $\mathbf{n ~ ( \% )}$ & $\mathbf{n ~ ( \% )}$ \\
\hline Class Level & & & \\
3. rd Grade & $98(22.0)$ & $90(20.2)$ & $188(42.2)$ \\
4. th Grade & $136(30.5)$ & $122(27.3)$ & $258(57.8)$ \\
Total & $234(52.5)$ & $212(47.5)$ & $446(100.0)$
\end{tabular}

Exploratory factor analysis based on the tetracoric correlation matrix was performed on the data obtained from 446 students within the scope of the construct validity studies of PSAS. 234 of the students are female (52.5\%), 212 are male (47.5\%) and 188 continue to 3rd grade $(42.2 \%)$ and 258 continue to 4 th grade $(57.8 \%)$. Whether the structure obtained by tetracoric factor analysis was verified or not was analyzed over the compliance statistics obtained as a result of the analysis. In addition, the confirmatory factor analysis was carried out and compliance values were examined. Before starting the factor analysis, the suitability of the data structure for factoring was tested. Kaiser-Mayer-Olkin Sample Size Test (KMO) and Bartlett Sphericity Test are used to analyze the suitability of the data set used in exploratory factor analysis applications. KMO is expected to be higher than .60 for factorizability (Büyüköztürk, 2011). The KMO value was found to be .89 , and since the Barlett's Sphericity test was significant $(\mathrm{p}<.01)$, it was seen that the data structure with these values was suitable for factor analysis.

Exploratory factor analysis based on tetracoric correlation matrix was performed for the factor structure of the scale. In each analysis made with the Varimax rotation method, the items that were not included in any factor or that were in more than one factor or whose factor load difference was less than 10 were excluded from the analysis. It was observed that the remaining 
20 items were collected in one factor. The factor loads of the data collected in one factor are shown in Table 2.

Table 2. Item loads of PSAS

\begin{tabular}{cc}
\hline Item No & Faktor Load \\
\hline 1 & .49 \\
2 & .45 \\
3 & .52 \\
4 & .79 \\
5 & .65 \\
6 & .56 \\
7 & .79 \\
8 & .60 \\
9 & .45 \\
10 & .61 \\
11 & .79 \\
12 & .54 \\
13 & .67 \\
14 & .76 \\
15 & .54 \\
16 & .65 \\
17 & .73 \\
18 & .69 \\
19 & .49 \\
20 & .38 \\
\hline & \\
Total Variance & .41 \\
Explained & \\
\hline
\end{tabular}

According to the values given in Table 2, the factor loads of the 20 item constituting PSAS vary between .38 and .79 .

The agreement statistics of the single-factor structure of PSAS were obtained by tetracoric factor analysis. Considering the goodness of fit criteria, chi-square / degree of freedom (2.14), NNFI (.98) and CFI (.98) and GFI (.96) values are the model's excellent, AGFI (.94) and RMSEA (.05) values of the model shows that it has good fit. Confirmatory factor analysis was also performed to see if the structure obtained by tetracoric factor analysis was confirmed. PSAS was performed to a total of 272 students, of which 147 were girls (54\%) and 125 were boys (46\%), 116 were 3rd grade (43\%), 156 were 4 th grade $(57 \%)$. As a result of the confirmatory factor analysis applied to the data obtained, it was observed that all of the items had a significant $t$ value (since it was seen to be above 2.56). According to the agreement statistics obtained as a result of the confirmatory factor analysis, chi-square / df $(351.42 / 170)=2.07$ and RMR $=.01$ values fit perfectly; NFI $=.87, \mathrm{NNFI}=.92, \mathrm{CFI}=.93, \mathrm{RMSEA}=.06$ and SRMR $=.06$ values indicate good fit. It is seen that two important fit statistics, AGFI (.83) and GFI (.86), are below the specified criterion value of .90 for acceptable fit.

\section{Item Analysis of PSAS}

In order to analyze the items of PSAS, the discrimination and item difficulty index of the items and the difference between the lower $27 \%$ and upper $27 \%$ groups were calculated. The discrimination indexes calculated for the items of PSAS took values between .37 and .71. Item difficulty indexes are between .56 and .85 .

According to the results of the $t$ test for comparison of the upper $27 \%(X=19.05, S S=0,83$ ) and lower $27 \%(X=7.78, S S=2.42)$ groups according to the total scores obtained from the PSAS, the difference between the two groups is significant $\left(\mathrm{t}_{(118)}=-34.07, \mathrm{p}<.001\right)$. 


\section{Similar Scale Validity of PSAS}

Similar scale validity of PSAS was evaluated by the Good Touch/Bad Touch Scale (Çeçen-Eroğul \& Kaf-Hasircl, 2013; Church et al., 1988). The calculations made with the data obtained from a total of 272 students showed that the pearson correlation coefficient was .66 $(\mathrm{p}<.05)$. This value indicates a medial relationship between the total scores of the two scales.

\section{Reliability Studies of PSAS}

The internal consistency coefficient of the scale calculated with the KR-20 formula was found as $.85(n=80)$. The test-retest correlation coefficient, which is calculated by applying PSAS to 79 participants with an interval of 4 weeks, is .79 (p<.01).

\section{DISCUSSION and CONCLUSIONS}

Empowerment of children is one of the primary measures that can be taken against sexual abuse of children. Although there is a history based on the mentioned education abroad in 1980s, the initiative on this issue in Turkey is still extremely limited. Although training programs have impelemented abroad since the 1980s, the initiatives on this issue in Turkey is still extremely limited. However, it is important for children to know good / bad touch, distinguish good / bad secret, recognize safe / unsafe situations, and know what to do when they encounter a situation or touch that bothers them. Considering that education programs have an impact on raising the knowledge and awareness, there is a need for assessment tools that can be used in the evaluation of the planned programs and in practices carried out in schools to prevent abuse and whose validity and reliability have been tested. This study was carried out because of this need.

Exploratory factor analysis based on tetracoric correlation matrix was performed using the varimax rotation method for construct validity of PSAS. In each analysis made with the Varimax rotation method, the items that were not included in any factor or that were in more than one factor or whose factor load difference was less than 10 were excluded from the analysis. It was observed that the remaining 20 items were collected in one factor. The total variance explained with one dimension is $41 \%$. It is sufficient that the variance explained in single factor scales is $30 \%$ or more. The high variance explained is interpreted as an indicator that the relevant structure is measured well (Büyüköztürk, 2011). Accordingly, it can be said that the explained variance value of $41 \%$ is sufficient.

The fit statistics related to the single-factor structure of the 20-item PSAS were obtained by tetracoric factor analysis. One way to describe the compatibility of the model with the data is by dividing the chi-square by the degree of freedom. If this value is below 3 , it means that the model has a perfect fit, and that it is below 5 indicates that the model has a moderate fit (Kline, 2005). Apart from this, the most used fit indices are GFI (Goodness of Fit Index), AGFI (Adjusted Goodness of Fit Index), RMSR (Root Mean Square Residual), RMSEA (Root Mean Square Error Approximation), NNFI (Non-Normed Fit Index) and CFI (Comperative Fit Index). GFI, AGFI, NNFI and CFI are higher than .90 are considered as a good fit value, and greater than .95 are considered as an indicator of perfect fit. In RMSEA, if the value is below .05, it indicates perfect fit and if it is below .08, it indicates good fit (Schermelleh-Engel, Moosbrugger \& Müler, 2003; Çokluk, Şekercioğlu \& Büyüköztürk, 2010). Considering the mentioned criteria, chi-square / degree of freedom (2.14), NNFI (.98) and CFI (.98) and GFI (.96) values of the model are excellent, AGFI (.94) and RMSEA (.05) values also indicate that the model has a good fit.

Confirmatory factor analysis applied to the data after exploratory factor analysis is an analysis in which a previously defined and restricted structure is tested whether it is verified as a model (Çokluk et al., 2010). While other than AGFI (.83) and GFI (.86), which are among the goodness of fit values obtained as a result of confirmatory factor analysis for PSAS, explain that the model has perfect and good fit, the two values were found to be below .90, which is the criterion value for acceptable fit. In a good model, these values should approach 1 . Based on the common opinion that all statistics should be evaluated together when deciding the harmony of 
the structure in the relevant literature (Tabachnick \& Fidell, 1996; Kline, 2000), the model has an acceptable fit.

One of the methods of item analysis performed for the validity of PSAS is the calculation of item difficulty and item discrimination indexes. Item difficulty and discrimination indexes are two values that show whether a substance distinguishes between the learner and not learner in the achievement test and the rates of being done correctly. A substance is a very weak item if its discrimination index is 0.19 and less, a substance that needs to be studied if it is between 0.20 0.29 , a good item if it is between $0.30-0.39$, and a very good item if it is 0.40 and greater. It can be said that the discriminative power of the scale is quite high, since the discrimination indexes belonging to the items of PSAS take values between 0.37 and 0.71 . In the item difficulty analysis, it shows that the items between 0.40 and 0.60 are of medium difficulty and it is an indicator that the items are reliable. It is an expected situation for the tests that the item difficulties are also at medium level, above 0.50 . The approach of this value to 1 can be interpreted as an indicator that the substance is an easy substance (Tekin, 2000). Difficulty indexes of scale items take values between 0.56 and 0.85 . When these values are taken into consideration, it can be said that all items of the PSAS meet the criteria set for discrimination and difficulty.

Another method used for item analysis is to compare the upper and lower $27 \%$ groups. The fact that a significant difference was found between the two groups as a result of the t-test performed for this can be considered as another evidence for the validity of the PSAS.

The Pearson correlation coefficient obtained as a result of the similar scale validity analysis of the PSAS using GTBT is .66 ( $\mathrm{p}<.05)$. This result can be considered as an indicator of the scale's similar scale validity.

Internal consistency coefficient was first calculated within the scope of reliability studies of PSAS. The internal consistency coefficient calculated with the Kuder-Richardson 20 (KR-20) formula obtained by calculating the percentage of individuals responding correctly to each item in the test was found as .85. It can be said that the internal consistency of the scale is at an acceptable level since the approach of this value to 1 indicates that the reliability has increased.

The test-retest correlation coefficient (.79), another reliability analysis, shows that the relationship between the first application and the second application scores is highly correlated. This result can be evaluated as proof that the scale meets the necessary criteria in terms of stability.

The psychometric findings of PSAS are that the scale is a valid and reliable measurement tool. Accordingly, it can be said that PSAS can be used in schools and scientific research to determine the personal safety knowledge and awareness levels of students attending the 3rd and 4 th grades. It can be used to assess students' level of knowledge before and after studies on sexual abuse by counselor teachers in schools. It can also be a guide for other measures to be taken in this way.

One of the negative consequences of the development of technology, due to the inappropriate use of technology, is one of the important risks faced by children in the virtual environment of abuse. Since PSAS contains substances to evaluate the risk of abuse and safe behaviors in the virtual environment, its use in schools and research is also important in terms of studies to be conducted to evaluate students' security behavior in the virtual environment.

Validity and reliability studies for different samples and different age levels of the scale can be done with future research. In the overseas literature review, it was seen that the effect of safety education was measured by the reactions they gave to the scenarios that were taken against the children as if they were real. For example, it is important to develop tools that measure students' personal safety skills through various scenarios, such as an adult seeking help from a child who does not recognize herself / himself to look for her/ his lost cat. In other words, the scales that evaluate whether the information acquired by children turn into skill should be developed. These studies will contribute significantly to the empowerment of children.

A limitation to this research is that it covers 3rd and 4th year students. It is thought that information about sexual abuse and personal safety of children should be given to cover all levels of primary school starting from pre-school period, and the necessary evaluations should be made to cover all levels of school. Since the cognitive characteristics and literacy skills of preschool and 
primary school 1st and 2nd grade students are different from 3rd and 4th grade students, two different measurement tools are needed. Two different types of studies exceed the scope of this research in terms of duration. For this reason, it is preferred to work with the youngest age group who knows how to read and write.

\section{REFERENCES}

Boden, J. M., Horwood, L. J., \& Fergusson, D. M. (2007). Exposure to childhood sexual and physical abuse and subsequent educational achievement outcomes. Child abuse \& Neglect,3 (10), 1101-1114.

Büyüköztürk, Ş. (2011). Sosyal bilimler için veri analizi el kitabı. Ankara: Pegem Yayıncılık.

Church, P., Forehand, R., Brown, C., \& Holmes, T. (1988). The prevention of sexual abuse: Examination of a program with kindergarten-age children. Behaviour Therapy, 19, 429-435.

Csorba, R., Tsikouras P., Lampe, R., \& Poka, R. (2012). The sexual abuse of female children in hungary: 20 years' experience. Arch Gynecol Obstet, 286(1), 161-6.

Currie, J., \& Spatz Widom, C. (2010). Long-term consequences of child abuse and neglect on adult economic well-being. Child Maltreatment, 15(2), 111-120.

Çeçen-Erogul, A. R.ve Kaf Hasirci, O. (2013). The effectiveness of psycho-educational school-based child sexual abuse prevention training program on Turkish Elementary Students. Educational Sciences: Theory and Practice, 13(2), 725-729.

Çocukların Cinsel Suistimal ve Cinsel İstrismara Karşı Korunmasına İlişkin Avrupa Konseyi Sözleşmesi \begin{tabular}{l} 
(2007). Avrupa Konseyi Sözleşmeler Dizisi. 201, 1-23. [Çevrim-içi: \\
\hline
\end{tabular} http://www.5te1.cocukhaklariizleme.org/avrupa-konseyi-cocuklarin-cinselsomuru-ve-istismarakarsi-korunmasi-lanzarote-sozlesmesi.html], Erişim Tarihi: 21.11.2016.

Çokluk, Ö., Şekercioğlu, G. ve Büyüköztürk, Ş. (2010). Sosyal bilimler için çok değişkenli istatistik. Ankara: Pegem Akademi.

Dube S.R., Anda R.F., Whitfield C.L, Brown D.W., Felitti V.J., Dong, M., \&, Wayne, H. G. (2005). Long-term consequences of childhood sexual abuse by gender of victim. Am J Prev Med., 28(5), 430-438.

Fergusson, D.M., Geraldine, F.H., McLeod, L., \& Horwood, J. (2013). Childhood sexual abuse and adult developmental outcomes: findings from a 30-year longitudinal study in New Zealand. Child Abuse \& Neglect, 37, 664-674.

Finkelhor, D. (2009). The prevention of childhood sexual abuse. The Future of Children, 19(2), 169-194.

Finkelhor, D. (2014). The lifetime prevalence of child sexual abuse and sexual assault assessed in late adolescence. Journal of Adolescence Health, 55, 329-333.

Fryer, G. E., Kraizer, S. K., \& Mlyoshi, T. (1987). Measuring actual reduction of risk to child abuse: A new approach. Child Abuse \& Neglect, 11(2), 173-179.

Gibson, L. E., \& Leitenberg, H. (2000). Child sexual abuse prevention programs: Do they decrease the occurrence of child sexual abuse? Child Abuse \& Neglect 24 (9), 1115-1125.

Herman, J. (1984). Sexual Violence. Work in Progress No. 83-05.

Kan, A. (2011). Ölçme aracı geliştirme. S.Tekindal (Ed.), Eğitimde ölçme ve değerlendirme içinde (ss.239276). Ankara: Pegem Akademi Yayıncılık.

Kline, P. (2000). Handbook of psychological testing (second edition). London and Newyork: Routledge Taylor \& Francis Group.

Kline, R. B. (2005). Principles and practice of structural equation modeling. New York: Guilford Press.

Maclntyre, D., \& Carr, A. (1999). Evaluation of the effectiveness of the Stay Safe primary prevention program fr child sexual abuse. Child Abuse\& Neglect, 23(12), 1307-1325.

Maniglio, R. (2014). Prevalence of sexual abuse among children with conduct disorder: A systematic review. clin. Child Fam. Psychol Rev., 17, 268-282.

Mendelson, T., \& Letourneu, E.J. (2015). Parent-focused prevention of child sexual abuse. Prev. Sci., 16, 844852.

Nickel, M. K., Tritt, K., Mitterlehner, F. O., Leiberich, Nickel, C., Lahmann, C., Forthuber, P., Rother, W. K., \& Loew, T. H. (2004). Sexual abuse in childhood and youth as psychopathologically relevant life occurrence: Cross-sectional survey. Croatian Medical Journal, 45(4), 483-489.

Paolucci, E. O., Genuis, M. L., \& Violato, C. (2001). A meta-analysis of the published research on the effects of child sexual abuse. Journal of Psychology, 135(1),17-36.

Putnam, F. W. (2003). Ten- year research update review: Child sexual abuse. American Academy Child\& Adolescent Psychiatry. 42 (3), 269-278.

Roberts R., O'Connor T., Dunn J., Golding J., \& The ALSPAC Study Team (2004). The effects of child sexual abuse in later family life; mental health, parenting and adjustment of offspring. Child Abuse\& Neglect, $25,525-545$. 
Rush, F. (1980). The best kept secret: Sexual abuse of children (p. 98). Englewood Cliffs, NJ: Prentice-Hall.

Russell, D.E.H. (1983). The incidence and prevalence of intrafamilial and extrafamilial sexual abuse of female children. Child Abuse and Neglect, 7, 133-146.

Schermelleh-Engel, K., Moosbrugger, H., \& Müller, H. (2003). Evaluating the fit of structural equation models: Tests of significance and descriptive goodness-of-fit measures. Methods of Psychological Research Online,8(2), 23-74.

Seydooğulları, S ve Kapçı, E. G. (2018). İlkokul 3. ve 4. sınıföğrencilerine yönelik cinsel istismarı önleme psikoeğitim programının geliștirilmesi ve etkililiğinin sınanması (Yayımlanmamıș doktora tezi). Ankara Üniversitesi, Eğitim Bilimleri Enstitüsü, Ankara.

Stoltenborgh, M., Van IJzendoorn, M. H., Euser, E. M., \& Bakermans-Kranenburg, M. J. (2011). A global perspective on -child sexual abuse: meta-analysis of prevalence around the world. Child Maltreatment, 16, 79-101.

Tabachnick, B. G., \& Fidell, L. S. (1996). Using multivariate statistics. New York: Harpercollins Publishers.

Tailor, K., Piotrowski, C.,Woodgate, R.L. \& Letourneau, N. (2014). Child sexual abuse and adult religious life: challenges of theory and method. Journal of Child Sexual Abuse, 23, 865-884.

Tekin, H. (2000). Eğitimde ölçme ve değerlendirme. Ankara: Yargı Kitapevi.

Tutty, L. M. (1995). The revised Children's Knowledge of Abuse Questionnaire: Development of a measure of children's understanding of sexual abuse prevention concepts. Social Work Research,19(2), 112120.

Türkiye İstatistik Kurumu (2017). Türkiye'de Cinsel Suç Mağdurlarının Cinsiyete Yaşa ve Son Üç Yıla Göre Değişimi.

Uçar, M. (2014). Bilişsel süreç yaklaşımına dayalı olarak hazırlanan cinsel istismarı önleme becerisi öğretim programının etkililiğinin incelenmesi (Yayımlanmamış yüksek lisans tezi). Abant İzzet Baysal Üniversitesi, Eğitim Bilimleri Enstitüsü, Bolu.

Wurtele, S. K., Gillispie, E. I., Currier, L. L., \& Franklin, C. F. (1992). A comparison of teachers vs. parents as instructors of a personal safety program forpreschoolers. Child Abuse\& Neglect, 16(1), 127-137.

Wurtele, S. K., Hughes, J., \& Owens, J. S. (1998). An examination of the reliability of the "What If Situations Test: A brief report, Journal of Child Sexual Abuse, 7, 41-52.

Wurtele, S. K. (2009). Preventing sexual abuse of children in the twenty-first century: Preparing for challenges and opportunities. Journal of Child Sexual Abuse, 18(1), 1-18.

Wurtele, S. K., \& Kenny, M. C. (2010). Partnering with prents to prevent childhood sexual abuse. Child Abuse Review, 19, 130-152.

Ziyalar, N. (1998). Cocukların cinsel istismardan korunması bir eğitim modeli önerisi (Yayımlanmamıș doktora tezi). İstanbul Üniversitesi, Adli Tıp Enstitüsü, İstanbul. 